\title{
Comparison of Carbapenem Resistance Detected by the BD Phoenix Automated System in Enterobacteriaceae Isolates with E-Test Method
}

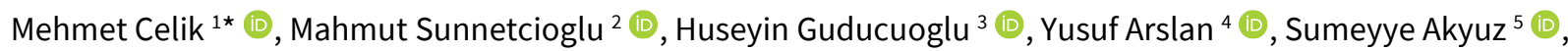 \\ Ali Irfan Baran ${ }^{2}$ (1)
}

\begin{abstract}
${ }^{1}$ Infectious Diseases and Clinical Microbiology Department, Medical Faculty Hospital, Harran University, Sanliurfa, TURKEY
${ }^{2}$ Infectious Diseases and Clinical Microbiology Department, Medical Faculty, Van Yuzuncu Yil University, Van, TURKEY

${ }^{3}$ Medical Microbiology Department, Medical Faculty, Van Yuzuncu Yil University, Van, TURKEY

${ }^{4}$ Infectious Diseases and Clinical Microbiology Department, Batman Training and Research Hospital, Batman, TURKEY

${ }^{5}$ Medical Microbiology Department, Mengucek Gazi Training and Research Hospital, Erzincan University, Erzincan, TURKEY

*Corresponding Author: dr.mcelik12@gmail.com
\end{abstract}

Citation: Celik M, Sunnetcioglu M, Guducuoglu H, Arslan Y, Akyuz S, Baran Al. Comparison of Carbapenem Resistance Detected by the BD Phoenix Automated System in Enterobacteriaceae Isolates with E-Test Method. Electron J Gen Med. 2022;19(3):em362. https://doi.org/10.29333/ejgm/11672

\section{ARTICLE INFO}

Received: 6 Aug. 2021

Accepted: 28 Jan. 2022

\section{ABSTRACT}

Objective: Automatic identification and antimicrobial susceptibility systems are frequently used to identify clinical isolates in hospitalized patients, but mistakes in these systems can lead to potentially devastating treatment failures for patients. Therefore, the "Centers for Disease Control and Prevention (CDC)" recommends confirming all Carbapenem-resistant and low-susceptibility isolates with a different method. The aim of this study is to compare the Carbapenem susceptibility results of isolates reported as Carbapenem-resistant Enterobacteriaceae according to the BD Phoenix 100 automated system with the E-test method.

Materials and Methods: The study included 70 strains of Carbapenem-resistant Enterobacteriaceae members which were isolated and grown from several types of clinical samples in the Medical Microbiology Laboratory. Conventional methods (Gram stain, negative oxidase test) and the BD Phoenix 100 automated system were used to identify the isolates. The susceptibility of all strains to imipenem, ertapenem and meropenem was investigated by E-test method. Automated system results and E-test results were compared.

Results: The frequency distribution of all isolated bacterial strains comprised $K$. pneumoniae in $56(80 \%)$ of the samples included in the study. The automated system test results were correlated with the results of the E-test at a rate of $96.1 \%$ for the imipenem-resistant strains, $84.3 \%$ for the meropenem-resistant strains, $84.1 \%$ for the ertapenem-resistant strains

Conclusions: Automated systems are frequently used in microbiology laboratories to identify isolates. However, automated systems can show a high error rate against some antimicrobials. For this reason, comparing the results of automated system test results with tests such as E-test is very important to prevent both treatment failures and inappropriate antibiotic use that may occur on a patient basis.

Keywords: Enterobacteriaceae, e-test, Carbapenemase

\section{INTRODUCTION}

Enterobacteriaceae is a bacteria family containing a large number of genera and species, which are often isolated as infectious agents from humans [1]. The main pathogens in this group include Escherichia, Klebsiella, Citrobacter, Enterobacter, Proteus, Providencia, Serratia, Hafnia, Morganella, Edwardsiella, Yersinia, Shigella, and Salmonella [2]. The rates of antimicrobial resistance have significantly increased in hospitalized patients in recent years [3]. Resistance mechanisms against Carbapenems basically involve $\beta$ lactamase production, and mutations altering the expression and/or functions of efflux pumps, porins, and penicillinbinding proteins (PBP) [4]. Carbapenem-hydrolyzing $\beta$ - lactamases (Carbapenemases) are the most potent, capable of hydrolyzing almost all $\beta$-lactams. Their worldwide spread among the members of the Enterobacteriaceae family creates a major concern [5]. Treatment options are limited and mortality rates are high in patients with infections, in which Carbapenem-resistant Enterobacteriaceae (CRE) are the causative agents [6]. In addition, the properties of the tested antibiotic also affect the susceptibility test results. For example, imipenem is easily degraded due to its instability. Although meropenem is more stable than imipenem, susceptibility panels, disc monitoring and storage conditions are required for both antimicrobials. Therefore, the "Centers for Disease Control and Prevention (CDC)" recommends confirming all Carbapenem-resistant and low-susceptibility isolates with a different method [7]. E-test (Epsilometer test) 
method is an antifungal and antibacterial susceptibility assay, introduced in 1988 [8]. This test serves as an alternative option to the reference methods as it is practical, easily applicable and it can provide the test results earlier compared to other existing assays [9]. In this study, it was aimed to compare the Carbapenem susceptibility results of isolates sent from the patients followed in different clinics of our hospital to the laboratory and evaluated as CRE with the BD Phoenix 100 automated system as a result of culture, using the E-test method.

\section{MATERIALS AND METHODS}

The isolates were obtained from clinical samples of the Van Yuzuncu Yil University Hospital Medical Microbiology Laboratory between August 2016 and August 2017, with minimal inhibitory concentration (MIC) value increase according to The European Committee on Antimicrobial Susceptibility Testing (EUCAST) criteria against at least one of the imipenem, ertapenem and meropenem antibiotics with the BD Phoenix 100 (Sparks, MD, USA) automated system were included in the study. Conventional methods (Gram stain, negative oxidase test) and the BD Phoenix 100 automated system were used to identify the isolates. All of the isolates included in the study were isolated from patients hospitalized at different dates and in different clinical units, and only one clinical isolate was accepted from each patient. During the study period, $70 \mathrm{CRE}$ strains satisfying these conditions were isolated and stored in glycerol broth storage medium at $-80^{\circ} \mathrm{C}$. The susceptibility of all strains to imipenem, ertapenem and meropenem was investigated by E-test (Biomerioux, France) method. A 0.5 McFarland turbidity bacterial suspension was prepared from the isolates and inoculated on Müeller Hinton agar (RTA, Turkey) plate. E-test strips were placed on the agar surface and incubated for 16-20 hours. At the end of this period, MIC values were determined by evaluating the imipenem, ertapenem and meropenem E-test results of all strains. Automated system results and E-test results were compared.

Descriptive statistics for continuous variables; It was expressed as mean, standard deviation, minimum and maximum values, while for categorical variables it was expressed as numbers and percentages.

\section{Ethical Statement}

Ethics committee approval dated 2016 and numbered B.30.2.YYU.0.01.00.00 was obtained from Van Yuzuncu Yil University, Faculty of Medicine Clinical Research Ethics Committee Presidency to carry out this study.

\section{RESULTS}

When the bacterial isolates submitted to the Microbiology laboratory were evaluated for their distribution by the clinical departments, it was observed that 28 (40\%) samples were found to be collected from the Anesthesia and Reanimation Intensive Care Unit (ICU), followed by the 12 (17.1\%) samples collected from the Neurology ICU, 7 (10\%) from the Internal Medicine ICU, and $5(7.1 \%)$ from General Surgery ICU, respectively (Table $\mathbf{1}$ ).

The frequency distribution of all isolated bacterial strains comprised Klebsiella pneumoniae in $56(80 \%)$ of the samples
Table 1. Distribution of clinical isolates by service/polyclinics

\begin{tabular}{lcc}
\hline Clinics & No. of isolates & $\%$ \\
\hline Anesthesia and reanimation ICU & 28 & 40 \\
\hline Neurology ICU & 12 & 17.1 \\
\hline Internal medicine ICU & 7 & 10 \\
\hline General surgery ICU & 5 & 7.1 \\
\hline Urology polyclinic & 4 & 5.7 \\
\hline General surgery service & 3 & 4.3 \\
\hline Orthopedics and traumatology service & 3 & 4.3 \\
\hline Infectious diseases service & 2 & 2.9 \\
\hline Chest diseases service & 2 & 2.9 \\
\hline Urology service & 2 & 2.9 \\
\hline Coronary ICU & 1 & 1.4 \\
\hline Oncology service & 1 & 1.4 \\
\hline
\end{tabular}

Table 2. Carbapenem-resistant Enterobacteriaceae (CRE) distribution

\begin{tabular}{lcc}
\hline Species & No. of isolates & $\%$ \\
\hline K.pneumonia & 56 & 80 \\
\hline E.coli & 10 & 14.3 \\
\hline P.mirabilis & 1 & 1.4 \\
\hline E.cloacae & 2 & 2.9 \\
\hline P.agglomerans & 1 & 1.4 \\
\hline
\end{tabular}

Table 3. Clinical samples submitted to the laboratory

\begin{tabular}{lcc}
\hline Clinical samples & No. of isolates & $\%$ \\
\hline Urine & 22 & 31.4 \\
\hline Tracheal aspirate & 18 & 25.7 \\
\hline Blood & 13 & 18.6 \\
\hline Wound & 8 & 11.4 \\
\hline Sputum & 4 & 5.7 \\
\hline Catheter & 4 & 5.7 \\
\hline Abscess & 1 & 1.4 \\
\hline
\end{tabular}

Table 4. Resistance rates on the Phoenix BD and E-test method

\begin{tabular}{lcccc}
\hline \multirow{2}{*}{$\begin{array}{l}\text { Test } \\
\text { method }\end{array}$} & \multicolumn{3}{c}{ Antibiotic resistance } & Total number \\
\cline { 2 - 4 } of strains \\
\hline Phoenix BD & $26(37.1 \%)$ & $69(98.6 \%)$ & $35(50 \%)$ & 70 \\
\hline E-test & $25(36 \%)$ & $58(83 \%)$ & $32(46 \%)$ & 70 \\
\hline
\end{tabular}

included in the study, followed by Escherichia coli in 10 (14.3\%) and Enterobacter in $2(2.9 \%)$ samples. All of the isolated strains are given in Table 2.

In the distribution of clinical samples, the majority of the samples are urine $(n=22,31.4 \%)$, tracheal aspirate $(n=18$, $25.7 \%)$, blood ( $n=13,18.6 \%)$ samples, respectively. Distributions of clinical sample types are given in Table 3.

Of the 70 isolates tested in the automated system, the highest rate of resistance was observed with the ertapenem (69 isolates, 98.6\%) among the studied Carbapenems. Resistance to meropenem and imipenem was observed in 35 isolates $(50 \%)$ and 26 isolates (37.1\%) respectively. The E-test results revealed resistance rates of $83 \%$ (58 isolates) to ertapenem, $36 \%$ (25 isolates) to imipenem, $46 \%$ (32 isolates) to meropenem. The resistance rates found by the automated system and the E-test method are given in Table 4.

\section{DISCUSSION}

This study was carried out to perform E-test on Enterobacteriaceae isolates with Carbapenem resistance detected in the automated system and to compare the two test 
methods. K. pneumoniae was the most common (80\%) isolated in the study. According to both automated system and E-test results, the highest rate of resistance was observed against ertapenem (98.6\% and $83 \%$ ). The fact that the Carbapenem resistance rate was found to be lower according to the automated system result compared to the E-test method indicates that Carbapenem resistance correlation with a different test is required.

Resistance to antibiotics in bacteria has been on the rise in the last 30-40 years. Nowadays, bacterial infections with multiple resistance are a major critical concern of physicians and a life-threatening issue for the patients especially in intensive care units [10]. In infections caused by Carbapenemresistant microorganisms; mortality and morbidity rates are high, hospital stays are longer, and treatment costs are increased. Furthermore, these infections are of critical importance because the world is running out of effective antibiotics, facing a rapid spread of resistance [11].

In the literature, the distribution of the types of samples, from which Gram-negative bacteria were isolated, is variable across studies. In 2011, the authors in [12] evaluated 1,346 Enterobacteriaceae strains isolated in 25 different microbiology laboratories from 23 different cities in Italy and reported that, of all the isolates, $48.6 \%$ were isolated from urine, $13.2 \%$ from blood, and $16.2 \%$ from the lower respiratory tract samples. Of 270 patients with Carbapenemase resistance, K.pneumonia growth was observed in 234 (86.7\%) patients. Carbapenem-resistant E.coli ratio was found to be $0.06 \%$. In a study conducted in Spain, K.pneumoniae was detected in $85 \%$ and $E$. coli in $1.7 \%$ in the bacterial isolates obtained from the patients with infections caused by Carbapenem-resistant enteric bacteria [13].

In a study conducted in Turkey, K.pneumonia was found in $70.5 \%$ and E.coli was found in $13.4 \%$ of the clinical isolates [14]. In another study conducted in Turkey, Carbapenem resistance was determined in $4.59 \%$ of Enterobacteriaceae family bacteria grown from various clinical specimens over a 3-year period, and the most frequently detected agent was Klebsiella spp. $(71.43 \%)$ [15]. Similar to the previous studies in the literature, the most frequent rate of growth was observed for the urine culture samples $(31.4 \%)$ in our study, too. This growth rate was followed by a rate of $25.7 \%$ for the tracheal aspirate cultures and $18.6 \%$ for the blood culture samples respectively. In regards to the bacterial growth, the growth of K.pneumoniae and E.coli were observed at a rate of $80 \%$ and $14.3 \%$, respectively. It was observed that K.pneumoniae was isolated more frequently similar to the previous studies in the literature.

Patients admitted to intensive care units (ICUs) are individuals often undergoing invasive interventions, receiving broad-spectrum antibiotics, and staying at the hospital for longer periods due to poor general condition compared to the other groups of patients [16]. In a study conducted in Italy [12], it was observed that $42.5 \%$ of the patients with Carbapenemresistant Klebsiella growth were inpatients in ICU. In a study in Mumbai [17], $12 \%$ of Carbapenem-resistant enteric bacteria were isolated from patients in intensive care units. A study conducted in Turkey observed that $42.9 \%$ of the isolates in the laboratory were prepared from clinical samples taken from ICU patients and they were mostly collected in Anesthesia and Reanimation ICU at a rate of $\% 26$ [18]. Similar to other studies, it was observed that the isolates were most commonly submitted by ICU's (72.8\%) in our study. The frequency distribution of ICUs revealed that the isolates were most commonly submitted by the Anesthesia and Reanimation ICU (40\%).

Many laboratories use automated identification and antimicrobial susceptibility systems to identify clinical isolates to save time, especially in hospitalized patients. Mistakes in these systems can lead to potentially devastating treatment failures for patients with CRE-related infections. Because of the significant morbidity and mortality caused by CRE-associated infections, it is very important for physicians to evaluate which drugs are the most appropriate option to treat these infections [19]. The Phoenix TM Automated Microbiological System is a system that provides rapid species-level bacterial identification and antibiotic susceptibility results of clinically important human bacterial pathogens. In addition, this automated system allows the identification of isolates with resistance mechanisms, including extended spectrumlactamases (ESBL), acquired $\mathrm{AmpC}$, and the identification of specific Carbapenemases in Gram-negatives [20].

E-test MBL (Metallo-beta-lactamase) strip method is used for identifying MBL-producing isolates. The E-test is among the methods determining MIC and it is more commonly preferred because it is easier and more practical compared to agar dilution [21,22]. A study, comparing disk diffusion, broth microdilution, E-test, and automated systems to determine susceptibility to imipenem, meropenem, and ertapenem, reported the E-test sensitivity as $58-90 \%$. This rate is higher, especially for ertapenem [23]. In a study which comparing the antibiotic susceptibility of bacteria isolated from urine culture with conventional methods and automated systems has shown that agreement for E-test was $95.3 \%$ with a very major error rate of 1.1 [24]. In a study comparing meropenem MICs and susceptibility with various tests in Carbapenem-resistant $K$. pneumonia strains; E-test demonstrated $82.6 \%$ agreement with broth microdilution MICs, a very major error rate of $2.2 \%$, and a minor error rate of $2.2 \%$ and Vitek 2 automated system MIC agreement was $30.4 \%$, with a $23.9 \%$ very major error rate and a $39.1 \%$ minor error rate [25].

Another study in which ertapenem resistance in the Enterobacteriaceae family was compared with different antimicrobial susceptibility tests and the broth microdilution test was used as the reference test, E-test showed high sensitivity and specificity (85.0\% and $88.5 \%$, respectively) and excellent concordance with BMD and the VITEK2 showed the lowest essential and categorical agreement $(30.5 \%$ and $27.8 \%$, respectively) [26]. It was observed that a resistance rate of 97.7 $\%$ to ertapenem was detected using antimicrobial gradient test techniques, whereas the resistance rate was $100 \%$ according to the $\mathrm{VITEK}^{\circledR} 2$ automated system [27]. Additionally, meropenem resistance was calculated using the antimicrobial gradient test $(93 \%)$ and the automated system (90.7\%).

In another study [28], metallo-b-lactamase (MBL) producing strains and Carbapenem resistance $K$. pneumoniae isolates were compared in terms of Carbapenem susceptibility with Vitek-2 and Phoenix automated systems and E-test methods. Phoenix showed higher categorical agreement $(97 \%$ for imipenem and $94 \%$ for meropenem) compared to Vitek-2 (92\% vs. $74 \%)$ and E-test ( $89 \%$ vs. $96 \%$ ) in detecting $\mathrm{MBL}$ strains. Categorical agreement for imipenem in detecting KPC producing strains was $88.4 \%$ with the Phoenix system, $83.2 \%$ with the Vitek 2 system, and $90.5 \%$ with the E-test. Also, categorical agreement was $100 \%$ for all tests with Ertapenem.

In this study the highest rate of resistance was observed with the ertapenem (98.6\%) among the studied Carbapenems 
(resistance to meropenem and imipenem 50\% and $37.1 \%$ respectively) according to the automated system. The E-test results revealed resistance rates of $83 \%$ to ertapenem, $36 \%$ to imipenem, $46 \%$ to meropenem. When E-test and automated system are compared; while the sensitivity rate of imipenem was similar in both tests, ertapenem and meropenem results were found to be lower in the E-test method. Although automated systems provide very important conveniences especially for hospitalized patients, erroneous results of the test can create a serious problem. The result of the automated system should be compared and verified with a different test under appropriate conditions.

\section{CONCLUSIONS}

In our country, Carbapenem-resistant Enterobacteriaceaerelated infections have increased significantly in recent years. In this study, it is seen that the most frequently isolated bacteria in the family of Carbapenem-resistant Enterobacteriaceae is K.pneumonia and the intensive care units is the hospital department where these resistant strains are most common. Although molecular methods are accepted as the gold standard in detecting Carbapenemases, they cannot be performed in every laboratory due to factors such as intensive labor, technical infrastructure and cost. Automated systems are frequently used in microbiology laboratories to identify isolates. However, automated systems can show a high error rate against some antimicrobials.

In this study, the rate of Carbapenem resistance was found to be higher than the E-test method according to the result of the automated system. For this reason, comparing the results of automated system test results with tests such as E-test is very important to prevent both treatment failures and inappropriate antibiotic use that may occur on a patient basis.

Author contributions: All authors have sufficiently contributed to the study, and agreed with the results and conclusions.

Funding: This work was supported by the Yuzuncu Yil University Research Fund as project number 93VF-219.

Declaration of interest: No conflict of interest is declared by authors.

\section{REFERENCES}

1. Bilgehan H. Enterobactericeae. Klinik mikrobiyolojik tanı [Enterobacteriaceae. Clinical microbiological diagnosis]. Izmir: Baris Yayinlari Fakulteler Kitabevi [Baris Publications Faculties Bookstore]; 2000. 102 p.

2. Toreci K. Enterobacteriaceae genel özellikleri [General characteristics of Enterobacteriaceae]. In: Willke Topcu A, Soyletir G, Doganay M (eds). İnfeksiyon hastalıkları ve mikrobiyolojisi [Infectious diseases and microbiology]. Istanbul: Nobel Tıp Kitabevleri [Nobel Medical Bookstores]; 2002. p. 1555.

3. Bradford PA. Extended-spectrum beta-lactamases in the 21st century: Characterization, epidemiology and detection of this important resistance threat. Clin Microbiol Rev. 2001;14(4):933-51. https://doi.org/10.1128/CMR.14.4. 933-951.2001 PMid:11585791 PMCid:PMC89009

4. Papp-Wallace KM, Endimiani A, Taracila MA, Bonomo RA. Carbapenems: Past, present, and future. Antimicrob Agents Chemother 2011;55(11):4943-60. https://doi.org/10.1128/ AAC.00296-11 PMid:21859938 PMCid:PMC3195018
5. Nordmann P, Gniadkowski M, Giske CG, Poirel L, Woodford $\mathrm{N}$, Miriagou V. Identification and screening of Carbapenemase-producing Enterobacteriaceae. Clin Microbiol Infect. 2012;18(5):432-8. https://doi.org/10.1111/ j.1469-0691.2012.03815.x

6. Gupta N, Limbago BM, Patel JB, Kallen AJ. Carbapenemresistant Enterobacteriaceae: Epidemiology and prevention. Clin Infect Dis. 2011;53(1):60-7. https://doi.org/ 10.1093/cid/cir202 PMid:21653305

7. Centers for Disease Control and Prevention. Guidance for control of infections with Carbapenem-resistant or Carbapenemase-producing Enterobacteriaceae in acute care facilities. MMWR Morb Mortal Wkly Rep. 2009;58(10):256-60.

8. Yildirim A. Extended spectrum beta-lactamase (ESBL) araştırma yöntemlerinin karşılaştırılması: E.coli ve Klebsiella spp. suşlarında sıklığının saptanması [Comparison of extended spectrum beta-lactamase (ESBL) research methods: E.coli and Klebsiella spp. Determination of the frequency in strains]. Uzmanlık tezi, Gülhane Askeri Tıp Akademisi [[Specialization thesis, Gulhane Military Medical Academy]], Istanbul, 1999.

9. Espinol-Ingroff A, Pfaller M, Erwin ME, et al. Interlaboratory evaluation of Etest method for testing antifungal susceptibilities of pathogenic yeasts to five antifungal agents by using Casitone agar and solidified RPMI 1640 medium with 2\% glucose. J Clin Microbiol. 1996;34(4):84852. https://doi.org/10.1128/jcm.34.4.848-852.1996 PMid: 8815095

10. Petrosillo N, Capone A, Di Bella S, Taglietti F. Management of antibiotic resistance in the intensive care unit setting. Expert Rev Anti Infect Ther. 2010;8:289-302. https://doi.org/ 10.1586/eri.10.7 PMid:20192683

11. Livermore DM. Current epidemiology and growing resistance of Gram negative pathogens. Korean J Intern Med. 2012;27(2):128-42. https://doi.org/10.3904/kjim.2012. 27.2.128 PMid:22707882 PMCid:PMC3372794

12. Giani T, Pini B, Arena F, et al. Epidemic diffusion of KPC Carbapenemase-producing Klebsiella pneumoniae in Italy: results of the first countrywide survey, 15 May to 30 June 2011. Euro Surveill. 2013;18(22):20489. https://doi.org/ 10.2807/ese.18.22.20489-en PMid:23787077

13. Oteo J, Saez D, Bautista V, et al. Carbapenemase-producing Enterobacteriaceae in Spain. Antimicrob Agents Chemother. 2013;57(12):6344-7. https://doi.org/10.1128/ AAC.01513-13 PMid:24041898 PMCid:PMC3837857

14. Us $E$, Kutlu $H H$, Tekeli $A$. Karbapenemaz üreticisi Enterobacteriaceae izolatlarının saptanmasında modifiye Hodge testi ile inhibitör tabanlı testlerinin karşılaştırılması [Comparison of modified Hodge test and inhibitor-based tests for the detection of Carbapenemase producer Enterobacteriaceae isolates.]. J Ankara Univ Fac Med. 2016;69(3):151-8. https://doi.org/10.1501/Tipfak_ 0000000937

15. Cayci YT, Biyıik I, Cinar C, Birinci A. Karbapeneme dirençli Enterobacteriaceae izolatlarının 2015-2018 yılları arasındaki antibiyotik direnci [Antibiotic resistance of Carbapenem-resistant Enterobacteriaceae isolates between 2015 and 2018]. Turk Mikrobiyol Cemiy Derg. 2020;50:134-40. https://doi.org/10.5222/TMCD.2020.134 
16. Yilmaz N, Kose S, Agus N, Ece G, Akkoclu G, Kirakli C. Yoğun bakım ünitesinde yatan hastaların kan kültürlerinde üreyen mikroorganizmalar, antibiyotik duyaklılıkları ve nozokomiyal bakteriyemi etkenleri [Microorganisms grown in blood cultures of patients hospitalized in the intensive care unit, antibiotic susceptibility and nosocomial bacteremia agents]. Ankem Derg. 2010;24(1):12-9.

17. Nair PK, Vaz MS. Carbapenem resistant Enterobacteriaceae from a tertiary hospital. J Microbiol Infect Dis. 2013;3(4):207-10. https://doi.org/10.5799/ahinjs.02.2013. 04.0110

18. Kutlu HH. Çeşitli klinik örneklerden izole edilen Gram negatif enterik bakterilerde karbapenemaz varlığının ve tiplerinin araştırılması [Investigation of the presence and types of Carbapenemases in Gram-negative enteric bacteria isolated from various clinical specimensi]. Uzmanlık tezi, Ankara Üniversitesi [Specialization thesis, Ankara University]. Ankara, 2016.

19. Haffler ZJ, Kulengowski B, Ribes JA, Burgess DS. Evaluation of the BD Phoenix automated system for determining antimicrobial susceptibility against Carbapenem-resistant Enterobacteriaceae compared with broth micro dilution. Int J Antimicrob Agents. 2019;54(2):249-54. https://doi.org/ 10.1016/j.ijantimicag.2019.05.002 PMid:31071467

20. Giani T, Morosini MI, D’Andrea MM, Garcia Castillo M, Rossolini GM, Canton R. Assessment of the Phoenix ${ }^{\mathrm{T} M}$ automated system and EUCAST breakpoints for antimicrobial susceptibility testing against isolates expressing clinically relevant resistance mechanisms. Clin Microbiol Infect. 2012;18:E452-E8. https://doi.org/10.1111/ j.1469-0691.2012.03980.x PMid:22909279

21. Miriagou V, Cornaglia G, Edelstein M, et al. Acquired Carbapenemases in Gram-negative bacterial patogens: Detection and surveillance issues. Clin Microbiol Infect. 2010;16:112-22. https://doi.org/10.1111/j.1469-0691.2009. 03116.x PMid:20085605
22. Baker CN, Stocker SA, Culver DM, et al. Comparison of e-test to agar dilution, broth microdilution and agar difusion susceptibity testing techniques by using a special challenge set of bacteria. J Clin Microbiol. 1991;29:533-8. https://doi.org/10.1128/jcm.29.3.533-538.1991 PMid: 2037671 PMCid:PMC269813

23. Anderson KF, Lonsway DR, Rasheed JK, et al. Evaluation of methods to identify the Klebsiella pneumoniae Carbapenemase in Enterobacteriaceae. J Clin Microbiol. 2007;45:2723-5. https://doi.org/10.1128/JCM.00015-07 PMid:17581941 PMCid:PMC1951220

24. Kocoglu ME, Davarci I, Guney R, Tascilar M, Zengin F, Samasti M. Comparison of conventional methods and automated systems for determining antibiotic susceptibility of bacteria isolated from urine culture. Bangladesh J Med Sci. 2019;18(3):519-26. https://doi.org/10.3329/bjms.v18i3.41620

25. Bulik CC, Fauntleroy KA, Jenkins SG, et al. Comparison of meropenem MICs and susceptibilities for Carbapenemaseproducing Klebsiella pneumoniae isolates by various testing methods. J Clin Microbiol. 2010;48(7):2402-6. https://doi.org/10.1128/JCM.00267-10 PMid:20484603 PMCid:PMC2897473

26. Lee M, Chung HS. Different antimicrobial susceptibility testing methods to detect ertapenem resistance in Enterobacteriaceae: VITEK2, MicroScan, Etest, disk diffusion, and broth microdilution. J Microbiol Methods. 2015;112:87-91. https://doi.org/10.1016/j.mimet.2015.03. 014 PMid:25794901

27. Sahin K, Tekin A, Ozdas S, et al. Evaluation of Carbapenem resistance using phenotypic and genotypic techniques in Enterobacteriaceae isolates. Ann Clin Microbiol Antimicrob. 2015;14(1):1-6. https://doi.org/10.1186/ s12941-015-0105-1 PMid:26444537 PMCid:PMC4596540

28. Sun J, Xu Y, Yu Y, Ni Y. Accuracy of in vitro susceptibility tests for Carbapenemase-producing Gram-negative bacteria. J Med Microbiol. 2015;64(6):620-2. https://doi.org/10.1099/ jmm.0.000067 PMid:25873580 